\title{
1. Jewish-Arabic collaboration through education
}

\author{
Amin Khalaf \\ Interviewed by Vered Zioni-Koren
}

Ever since I can remember, I wanted to be a teacher. The idea of inculcating knowledge - and more importantly, values - leading and shaping the next generation has always fascinated me. I first heard of Amin Khalaf and his vision of bilingual education in Israel while studying for my MA at the Seymour Fox School of Education of the Hebrew University of Jerusalem. I was glad I had this opportunity to interview Amin because I strongly believe that our society has the ability to work towards coexistence and that education can reshape thinking patterns and change realities.

I met a young idealist who was merely looking for an educational institution for his children that would reflect his wife's and his approach to education. When he failed to find one, he decided he'd establish it! Amin's charisma was captivating and inspiring. While his eyes shone with uncompromising passion, his face and manner of speech gave away hard feelings of sobering up, disappointment, helplessness, and questions about the ideology and values that Israel is headed towards at the onset of the 2020s.

\section{WHY DO THEY HAVE AND WE DON'T?}

Generally speaking, I consider myself a social entrepreneur. What is that? It is a person who looks around him, sees reality, and thinks of ways to improve it, to make the world more just and life better for everyone - myself as well as others. This characterizes the way I do things. It is a positive thing that I like about myself, and hope it will remain like that for the rest of my life.

It all started at the home in which I grew up, the small-village atmosphere. I was born in the village of Muqeible in the Jezreel Valley and I believe my family context was important. I am the son of a second marriage, my mom's only son, and, after two girls, the youngest child in our family. As a result, I had a lot of freedom to think, observe, deliberate, and decide. I had no 
dominant role model as a child. I was free. At home, I had older half-brothers, and some of them were socially active. They used to argue and debate, so I heard all about political values and the struggle for equal rights at home. That encouraged me.

I had many experiences as a child, but I hardly remember them. My sister used to make my lunch for school. One morning, I could not find her. I searched all over until I saw her crying behind the door. When I asked what had happened, she told me she was crying because the Egyptian president Gamal Abdel Nasser had died. We had his picture at home. In 1973, Egypt and Israel were at war known as the Yom Kippur War, Ramadan War, or the October War. We were scared, and it was hard for us to understand what was going on. People's cars were taken, we had to turn off the lights at our homes, things like that. We did not speak with the adults, heard nothing, asked nothing, and had no answers. We had to figure it all out ourselves.

When I turned 13, it was a very significant time for me - early adolescence and the identity-forming years. Being raised in a village, I was lucky, but also unlucky. Our village had no electric power before I was 10. People my age don't always remember, but ours was a deserted and neglected village with no infrastructure. At 13, in seventh grade, I loved to stand on a hill in the village and look north. They were finishing the construction of a new Jewish village named Magen Shaul, and I remember watching it: There were roads, a basketball court, a nice swimming pool. Then I started forming the identity question: Why do they have, and we don't?

So, I started looking for answers and a better understanding. It did not make me feel hatred or alienated; just the opposite: I wanted what people on the Jewish side had. I never really hated anyone. I could get angry or feel disappointed, but not hatred. I wanted to change things. If something is not good, I try to change it.

\section{DISCOVERING MY LEADERSHIP SKILLS}

At 13, I discovered my leadership qualities. My village used to mark Israeli Independence Day, and it was every child's dream to lead the Scouts in the march and carry the national flag on that day. That privilege was usually assigned to the best pupil, and I aimed at that too. Yet, something went wrong. Frankly, without any preparation, I don't remember talking about this to my friends, brothers, or other family members. Ahead of Independence Day, our teacher came to class and said: "We need to decorate this classroom for Independence Day." This is not the first time that I tell this story, and I still don't understand how I summoned the courage to stand up and say: "We don't want to." Even today, I say, wow! Where did that courage come from? I felt that it was the Independence Day of the State of Israel, not ours - second-rate 
citizens and members of the Palestinian nation. My refusal swept the entire class. I am sure it was mixed with fear. I don't remember what happened next exactly, but the teacher said that those who don't want to decorate may play in the yard, so we got up and went out - all of us, except for two girls who stayed behind to help the teacher. I remember feeling happy that it happened, but also wondered: What the hell happened here?

I was a good, nice, and likable boy, a good pupil too. I am not a rebel even today. I believe everyone in school was surprised. I was the leader of the Scouts at school that year, and we won the first prize in the annual Mount Tabor Walk of the National Scouts Movement. That was some achievement for a small and low-income village such as ours. The prize was a hike, but because I rebelled on Independence Day, they told me I could not go. They took the leadership position from me and gave it to another kid who was my best friend and cousin. They tried to drive a wedge between us. Those were hard days for me, and I don't remember that I had explicit support at home. Of course, they supported me, but they never said things like: "You are in the right direction," or "Do this and that," so I also experienced worries and uncertainty.

\section{FROM THE VILLAGE TO THE BIG WORLD}

I graduated from grammar school and was accepted to a good high school in Nazareth, which made me proud. It was a dream come true for me. Initially, I wanted to study at ORT Afula, a vocational high school, and learn a profession, but I was told that was impossible. Then I read in a youth magazine that 99 percent of the students of that Nazareth school earned matriculation certificates. It sounded good, so I said: Yalla, let's go there. I listened to my mother who, when she was still alive, always said: "Education, education, education, that's the only way to get ahead in life and out of the poverty and remoteness cycle." Over the year, two main voices guided my life. The first was being an active member of the Israeli Communist Party (Rakah), which could block the access to good things in this country. The second was my mom's voice, saying: "Study hard and be a good boy." It's important for me to keep a balance between these two voices in my life.

I stayed in the village and commuted to Nazareth every day. We used to get off the bus at the entrance to Nazareth and walk up to school. Nobody does that today. In the evenings I'd return to my village, but I was incredibly frustrated because of that then. I wanted to live in the big city, join the school volleyball team, catch a movie, do things with other kids - but I couldn't. After school, I had to run to catch the bus because there was no other transportation home. I mean, there were buses from Nazareth to Afula, but none from Afula to the village. If I missed that bus, I was simply stuck. I am not sure that today's kids can understand this because the world has changed. Our parents had no 
cars or mobile phones. Today, kids can call their parents to pick them up. It is a different world.

The Nazareth school was good. It had a well-known headmaster, and he had a good effect on us. My world expanded. One of the most important things that happened and had a significant impact on me took place when I was in tenth grade of high school. There was an attempt to assassinate West Bank notables Bassam Shakaa and Karim Khalaf. Explosives were planted in their cars and Shakaa lost both his legs. That morning, our school devoted two hours to discuss the event. I went home that day, fearing that the Education Ministry would close down our schools. These were my fears. I mean, it is OK for Jewish schools to have the kids discuss current affairs, but we were not allowed to talk about such things. In seventh grade, still in the village, our headmaster spent an entire semester of civic lessons explaining that there is no Palestinian nation. We heard him but lacked the power or the knowledge to respond, which made us angry. In Nazareth, things were different. We went to school the next day, and it was open, so I gathered that we could discuss political issues, and no disaster would strike.

When I was in tenth grade, I discovered that we were entitled to a transportation refund from the Ministry of Education. But there was no one to arrange that. A year later, I went to the ministry headquarters in Jerusalem and started looking for the person who should give me a refund. This is nothing like the world of kids today. Then, we had the desire to seek justice. That Nazareth high school gave me something.

Then I went to university, which was quite a change, from a small village to Jerusalem. The world expanded further. The Hebrew University opened new worlds for me. I took courses in Arabic language and literature, and Islamic and Middle Eastern studies. There, I could study and discuss the history of the Israeli-Arab conflict and hear the Palestinian narrative.

Living in Jerusalem was great fun. Arab students surrounded me, and there was political activity, to which I dedicated hours. I was very active, and it sharpened my worldview. With all the debates among the Arab students and between the Jews and us, I became politically aware. We lived actively, studied, and thought. In my junior year, we staged a protest rally outside the Prime Minister's Residence, yelling and chanting slogans. I was afraid someone would come out and attack us, but this is a democratic country, and demonstrations are allowed. You can chant slogans, and nothing will happen to you. I felt I had a lot of latitude. In those years, I understood what the State of Israel was, what the Palestinian problem was, and what equal rights were. I met the leaders of the Arab population, and it gave me a lot of strength and knowledge.

At 26, I was active on the Jewish-Arab issue, but mainly with Arab students. I was also a journalist. Then the first intifada started, and things became more 
difficult. Later, I took a group facilitator's course at Neve Shalom, or Wahat al-Salam in Arabic, where I learned how to facilitate Jewish-Arab dialogue meetings. I also met my wife there. We're both educators. After the course, I served as a grammar school teacher at Neve Shalom. It is an extraordinary school that gave me plenty of knowledge relevant to things I did later, and I became involved in education. For me, the two great things that happened during that period were that I became increasingly involved in Jewish-Arab dialogue meetings, and I started instructing teachers at the School for Peace and then worked with Peace Child YMCA Israel.

\section{"I BELIEVED IT COULD BE DONE": HOW THE BILINGUAL SCHOOL IN JERUSALEM WAS ESTABLISHED}

After graduating from university, we stayed in Jerusalem and had a son. When he was two years old, we sent him to the YMCA kindergarten in the city center. His class comprised half Jewish and half Arab children, so they named it Gan Shalom - the Peace Kindergarten. I then started wondering where we'd send him to school. In those years, I was a class teacher in Jerusalem, in the high school of Beit Safafa and the Givat Gonen elementary school, so I was familiar with Jerusalem's school system. I became angry once I learned that schools in the western, Jewish part of the city prepare their students for the matriculation certificate, while schools in the eastern, Palestinian part do not. I also knew Arab children who went to Jewish schools on the western side, and I realized that this arrangement does not work well! I became convinced that I made the right decision not to go to ORT Afula for my high school studies. The two populations are very different, so it is not easy socially when you are different and have a hard time fitting in. We realized that sending our son to the Givat Gonen school on the western, Jewish side of Jerusalem would be complicated. Still, sending him to some East Jerusalem, Palestinian school would be problematic too. What do we do then? We decided to find a school where children prepare for matriculation exams in Arabic - which did not exist then. We started thinking about doing something even more meaningful in the education system. Then, someone introduced me to Lee Gordon, who had graduated from the Mandel School for Educational Leadership, and was thinking about establishing a joint Jewish-Arab kindergarten - and wow! We hit it off right away.

And so it started. All of these things together - finding an educational facility for our son, the YMCA kindergarten, my experience at Neve Shalom, and the desire to do something meaningful and promote Arab-Jewish collaboration in the State of Israel - helped me connect so well with Lee Gordon, who brought the idea of starting a joint kindergarten. Naturally, I had my own 
ideas. I was thinking of starting a class of Arab pupils in a Jewish school. Lee wanted a kindergarten, and I wanted a class, and we got together and got things rolling. First, together with several other people, we formed an association that we named 'Learning to Live Together' to open a kindergarten similar to the one at the YMCA. Then we established 'Hand in Hand,' a bilingual center designed to promote bilingual education in schools. Lee came from his world, and I came with my experience, and we started a dialogue and connected. We wrote down our vision, a page and a half, and were going to change the world. One of the things that we had in common and helped us was daring to jump in with lots of questions. It was all semi-voluntary, but we had a beautiful idea written on a piece of paper: To promote a joint civil society for Jews and Arabs in Israel through education. That is, establishing shared educational frameworks.

I was really excited, believed in it, felt it was possible. I spent a whole year in the Neve Shalom school, so I could answer many questions. Also, I have a lot of experience in education and I am a group facilitator. I can explain how teaching in two languages can be done. That helped us. The Hand in Hand Center for Jewish-Arab Education in Israel, our association, was a huge success story. After only 18 months of activity, we have established two schools in the north of Israel and Jerusalem.

The reason for the latter is apparent. I needed a kindergarten for my son. But why the Northern District? Because the director there loved our idea and said: Go ahead, find partners, and I am with you. So we started, and Lee obtained a list of Education Department managers in the Ministry of Education's Northern District. We began arranging meetings and traveling north while working on the Jerusalem project.

The first positive answer from the Jewish side came from the Misgav Regional Council in the Northam District, and we started a school there with partners we found in the region. I needed to understand how to connect the dots because Hand in Hand was a complicated project. For example, to form the steering committee in the Galilee, we had to find people from the Education Ministry, the Misgav Regional Council, Sakhnin, public figures, and parents. Finding partners is one of my strengths. When people asked me how I do that, I used to say that I use my 'gut feeling' - but now I think it is accumulated experience. It is like going back to my childhood and asking, why did your classmates follow you? Or, how do you make people believe in you? It just happens. I believe that accumulating experience is the road to leadership.

At the time, Meir Krauss, head of the Education Directorate of the Jerusalem Municipality, sent us messages saying this was not the right time to promote our ideas in Jerusalem. This was the mayor's stand. We might have given up anywhere else, but not in Jerusalem. I mean, I needed an educational institution for my son! So we established a small local framework in the Experimental 
School in Jerusalem. If I remember correctly, the entire YMCA class joined the Experimental School with nine Arab and three Jewish pupils. But we had all kinds of problems at the Experimental School. The hardest thing was their resistance to change. Things ran smoothly in the first year, but I guess it is not simple to change systems. For example, we wanted the pupils to study 20 minutes in Hebrew and 20 minutes in Arabic in each lesson, but the Experimental School said this was too much. In the second year, when another YMCA class came, they said they would let in only those who meet the Experimental School's criteria. A world war broke out, parents were disappointed, but I also felt that we could not disappoint our Jewish partners. That started real problems.

That same year, Lee Gordon left for the United States, and Haim Erlich, the Experimental School headmaster, left his position and became my partner. We encountered more and more problems: Members of the school steering committee started arguing, and racist remarks were made. I remember how the parents had a meeting to decide if they wanted us or not. It was one of the most racist encounters I had ever attended. Harsh words were spoken against the Arab parents, and many left the meeting in tears. They kicked us out, saying: "We don't want you anymore." That experience still shakes me today. I was humiliated, but I had to shut up and not talk too much about this, not rock the entire project. I never prepare notes when I speak publicly, but I had things written down in that meeting. We did not talk much, and there were things that I wanted to say - but couldn't: "How can you kick us out like that? Why do you humiliate us?" The fantasy of making the Experimental School a sort of "mini Israel' had failed. What were we thinking? Did we really believe that if 20 percent of the students were Arabs, that would change things at the state level?

That year, we devoted our efforts to the establishment of an independent school in Jerusalem. Yossi Sarid was education minister and Ehud Olmert was the mayor of Jerusalem. We worked very hard, and Olmert told us: I am with you 100 percent. Indeed, over the years, Olmert was the most important political figure for us. He truly supported us. The Municipality gave us a small building with two classrooms next to Denmark School in the Katamon neighborhood. Our most challenging class comprised the Experimental School graduates because when we left there, none of the Jewish students came with us. We were able to attract no one. The graduates were second graders; the first grade was steady, and we managed to establish a kindergarten - so we had three classes. They gave us a room, but there was no yard for the kids. Then, I invited Mayor Olmert for a visit, and he came with a large entourage. He looked around and said: "Where is the yard for these children?" The next day, they broke down a wall and made a passage for us to the yard. Later, we kept expanding at the expense of the adjacent Denmark School, which was very difficult because we had to fight for every classroom. After the idea started 
succeeding, the Jerusalem Fund stepped in and, thanks to contacts with the Municipality, gave us a piece of land. We raised some money and built the school. My three children attended it; two graduated, and my daughter is going to the eleventh grade next year.

We tried to do the same in Haifa, but it did not work. In Jaffa we had a kindergarten for one year before it shut down. Next, we established a partnership with an association in the Wadi Ara area and opened our third school in Kafr Qara. Several years later, partnering with an association from Beersheba, we established a kindergarten and then an elementary school there, but it failed. Today, we have four educational institutions: in Jerusalem, Misgav, Kafr Qara, and Beersheba. Only in Jerusalem did we develop it into a high school, but we tried all over the country.

That was very meaningful - the most significant - time in my life. We established schools believing that we were creating a model for an egalitarian Jewish-Arab partnership. We believed that we could teach everyone about living together in the State of Israel in terms of language, culture, and nationality. In those years, I honestly thought we were changing the world. Today, of course, my view is far more critical, and I have some questions, but things were very good and significant at the time.

\section{EQUALITY IN LANGUAGE, CULTURE, AND NARRATIVE: THE HAND IN HAND WORLDVIEW}

The basic concept of Hand in Hand is that children get to grow together which none of us had experienced - maintaining equality on three levels: two languages, two cultures, and two narratives. I focus on equality because it is clear that we need it if we want to make peace. Both sides need to gain. At Hand in Hand, we don't use the word coexistence too often and speak more of civilians' partnerships and equality. When I established Hand in Hand, I had this fantasy that leadership that would change reality would emerge from it. I envisioned that every person that wants to learn how to become a leader would learn from our experience.

To establish a meaningful and equal Jewish-Arab partnership in our school, we decided on three practical pillars that reflected the three cycles: language, culture, and narrative. The first pillar is the bilingual concept: we wanted children who grow in the Hand in Hand system to speak both Hebrew and Arabic, and each pupil should choose the language he or she prefers. Languages reflect the balance of power in society. If we want to change it and promote equality, Jews need to know how to speak Arabic. The second pillar is culture, which means celebrating each other's holidays. The third pillar comprises narratives - making room for the national stories of both sides. Also, equality is 
expressed on the administrative level - we have two teachers in each class and two headmasters for every school.

One of the things I tried, to no avail, was to convince the Ministry of Education to reward bilingual teachers. If we believe that bilingualism - speaking both Hebrew and Arabic - is an advantage for teachers, and if the system rewards bilingual personnel, it would have a significant impact on the power relations between the languages and the people. If every bilingual teacher in Hand in Hand had been paid 10 percent extra, bilingualism would have had a real value. I hoped we could encourage the Jewish teachers to learn Arabic and collect the reward. If it was a very significant reward, not 10 percent but even an extra 20 percent to their wages, they might have even learned to master Arabic and used it daily. We tried to get the Ministry of Education to approve our dual teaching method - a Hebrew-speaking and an Arab-speaking teacher for each class. Even the Dovrat Committee (the National Task Force for the Advancement of Education in Israel) recommended that additional budgets for Hand in Hand be considered. I promoted this agenda, but it was hard, and we failed in rewarding bilingual teachers. I wanted to continue this struggle against the Ministry of Education, produce position papers on bilingualism and multiculturalism, and establish a learning center. Still, forces from within and without the organization held me back.

In my ideal world, we have to work to make Arabs speak perfect Arabic and have Jews speak some Arabic, but beyond that I wish to write a position paper addressed to the government, explaining how the State of Israel should manage language. It is clear that Israel cannot be entirely bilingual, nor can I insist that 80 percent of the Jews here speak both languages, but the reality is a far cry from all that. Another dream of mine, of which I wrote or did nothing, is the need to have bilingual education in towns where Arabs are above a certain population percentage. I mean, it is inconceivable that government officials in Arab towns do not speak both languages. For example, you cannot appoint a National Insurance director who is not bilingual in Nazareth. If government tenders made that requirement, it would make learning Arabic more critical and give its speakers an advantage.

\section{BETWEEN EDUCATION AND IDEOLOGY}

I was raised on the belief that Arabs in the State of Israel should be equal. I believed that through the experience gained at Hand in Hand, we would have the specifics of how that equality would look and, even before it came, how Israel should exist as an egalitarian state. When we started with Hand in Hand, we talked about Israel's nature - whether it is Jewish and Zionist, or a state of all of its citizens. I believe we should be addressing this issue because we need to create answers. These are neither academic nor political issues. We 
tried to figure out the solutions based on experience accumulated at Hand in Hand. When people ask me what was the most formidable challenge, I say: Human resources. The most challenging task was selecting directors for our schools, considering both ideological and educational aspects. I focused more on the ideological side. It may have been a mistake. I don't know. It mattered to me that we chose principals who were more committed to the association's ideology and less education-oriented. I may have been wrong.

I wanted the school to make social statements on issues such as Land Day, for example. If the Arab sector calls a general strike on that day, should our Arab teachers strike too? I thought they should, but most of the teachers did not. That initiated a debate on how schools bring populations together. The Arab parents told us that they wanted a place for their children to study well so they could go to university and be with educated people. The Jewish parents disapproved of the Arab teachers' strike, feeling it was against them - a very complicated thing. We had to conduct many discussions when most of our Jewish and Arab partners were against these discussions - they just wanted a school. It is not simple to manage a Jewish-Arab partnership. When we discussed Land Day, for example, the Jewish parents argued that Arabs stress the importance of land while Jews emphasize the value of human lives. The explanation is that each side focuses on what it lacks. The Palestinians don't have a state, and they worry that their remaining land might be seized, so they care about land, which is not to say that human lives don't matter. The Jews, on the other hand, have a state and land, so it is easier for them to talk about humanism. I believe it reflects some hidden racism that is hard to explain and not simple to clarify.

Succeeding with children requires great investment in their parents. Children go home to their parents and the parents decide where children of those ages study, so parents are part of the change. In the beginning, some parents were worried about the effect of the encounter with the other side's culture on the children's identity. Early on, when Jewish children entered a 'mosque' that we built inside one of the classrooms to mark the month of Ramadan, some parents felt it was the end of the world! Why? Some issues were religious and cultural, but also national. We wanted to mark the Palestinian Nakba Day and learn about Land Day, but the Jewish parents were worried, so we had to discuss it with them because parents are part of the change. I know that the parents created some of the difficulties in the Bilingual School. We invested quite a lot in this, and it helped, but when parents were bilingual, we had better chances of succeeding. Even today, I can speak of small things we failed in. For example, we wish that we had taken the symbolic step of buying trilingual computer keyboards for the families. The children were already learning two languages, so I wanted them to have trilingual keyboards at home like those they had in school. 
External reality sometimes makes things hard too. We started in 1998 and until 2000, we were on the rise. After the October 2000 events we had to maintain what we had, and we could not dream and fantasize as we had done beforehand. I used to believe that Hand in Hand should be a beacon that lights the way for everyone, but after the Second Intifada (aka, the Al-Aqsa Intifada) I started viewing our schools as a rare flower that needed protection. Our optimism began to change in many respects when things deteriorated after 2000. There was great hope for real peace in the region before that, but 2000 was a year of crisis. We started thinking: What is the point of forming such partnerships when there are occupation and war? How do military service and school involvement combine? Many sensitive questions that address the complexities of complexities. Not simple at all. I don't have the answers to these questions. I just don't know.

\section{NEVER GIVE UP}

Can social change be promoted through education? I am still deliberating and have no answer for this question. It remains open. If the answer is negative, then the investment we made was wasted; if it is positive, we need to introduce the necessary changes and continuously develop our critical views. It runs even deeper than that. My high school had a very positive impact on me, and I believe that there are good Jewish schools that make a difference. Still, when it comes to the issue of Jewish-Arab partnerships, there is an interesting and fascinating question that has not yet really been examined: Do both sides genuinely gain from it?

I quit as Hand in Hand chairman after 14 years on the post. I felt I'd exhausted it. I wanted to grow with Hand in Hand and expand our influence and reach beyond the school, but the board and our donors were against it. Some argued that our only mission was to establish schools. Still, I believed we should go further, formulate and disseminate our knowhow and truly impact larger populations and policymakers. I've always encountered resistance from the partnership's Executive Committee and mainly from our Jewish donors. That naturally added up to all kinds of grievances and problems in the organization and the school. Still, the most important thing for me was that I felt I had done all I could. On my part, I made the school dream come true and established four educational institutions that cover this country from north to south. That's the image I had in my head.

I am at peace with my decision still. I remember how, during the Second Intifada, people in my village - only some $4 \mathrm{~km}$ from Jenin - would sit on their porches, watching the Jenin refugee camp and seeing the chaos that went on there, the pain and the rage. When I returned to my village, people asked me: "So, do you still believe in what you do?" and I said: "Yes, I do." That was my 
answer, even when I encountered difficulties. For example, my entire family resides in the West Bank. When my Uncle Amin passed, we wanted to attend the funeral. At the crossing, we felt very humiliated. I wanted to tell the soldier there: "Do you know what I do?!" but I choked and said nothing. That's hard!

To connect the present moment with the day I was 13 and refused to celebrate Israel's Independence Day, something inside me says: Never give up! It is hard for me to live in the State of Israel even today, but I do whatever I can. I believe that most people are busy with what's suitable for them and for their families, and less with what happens around them. That's legitimate. I am the kind of person who worries about the greater good and those things around us. I want to change the world, make it a better place, more just and egalitarian. That's how I was, that's how I am, and that gives me strength. I still want to make some changes, even today. I want to help the East Jerusalem residents learn Hebrew. I want to promote sustainability issues and impact on the world as a whole. So, to endure and not retract into your bubble, you must be an optimist. At the time, I used to say that I dream of 10 such schools in Israel. Today, I believe that six-seven schools constitute quite a fitting dream. I still wonder if I could go back and turn Hand in Hand into a lab to create a model for an egalitarian State of Israel. It would not be not easy, but it is possible.

Today, I have a critical view of things. I think about what can be done or promoted, which is why I speak of thoughts and questions. The most important thing is that I am not losing hope, still believe in what I've done so far, and want to keep doing it. I keep trying. 